\title{
New clinical developments in histone deacetylase inhibitors for epigenetic therapy of cancer Shundong Cang ${ }^{1,2}$, Yuehua $\mathrm{Ma}^{1,2}$ and Delong Liu*1
}

\begin{abstract}
Address: ${ }^{1}$ Division of Hematology/Oncology, New York Medical College, Valhalla, NY 10595, USA and ${ }^{2}$ Henan Province People's Hospital Zhengzhou, PR China

Email: Shundong Cang - shundongcang@yahoo.com; Yuehua Ma - HAL19831116@yahoo.com.cn; Delong Liu* - delong_liu@nymc.edu

* Corresponding author
\end{abstract}

Published: I June 2009

Journal of Hematology \& Oncology 2009, 2:22 doi:10.1 186/1756-8722-2-22

This article is available from: http://www.jhoonline.org/content/2/l/22

(c) 2009 Cang et al; licensee BioMed Central Ltd.

This is an Open Access article distributed under the terms of the Creative Commons Attribution License (http://creativecommons.org/licenses/by/2.0), which permits unrestricted use, distribution, and reproduction in any medium, provided the original work is properly cited.

\begin{abstract}
DNA methylation and histone acetylation are two well known epigenetic chromatin modifications. Epigenetic agents leading to DNA hypomethylation and histone hyperacetylation have been approved for treatment of hematological disorders. The first histone deacetylase inhibitor, vorinostat, has been licensed for cutaneous T cell lymphoma treatment. More than II new epigenetic agents are in various stages of clinical development for therapy of multiple cancer types. In this review we summarize novel histone deacetylase inhibitors and new regimens from clinical trials for epigenetic therapy of cancer.
\end{abstract}

\section{Introduction}

DNA methylation and histone acetylation are two most studied epigenetic modifications, although ethyl, acetyl, phosphoryl, and other modifications of histones have been described $[1,2]$. Histone acetylation and methylation have been studied extensively in carcinogenesis [3]. Histone acetylases (HATs), histone deacetylases (HDACs), histone lysine methyltransferases (HMTs), and histone demethylases are key enzymes involved in epigenetic regulation and chromatin remodeling. Coordinated DNA methylation and histone modification play a key role in the control of gene expression [2]. Vorinostat (Zolinza, Merck) is the first HDAC inhibitor that has been licensed for clinical use [4-10]. More than 11 HDAC inhibitors are in clinical development. In this review we summarize novel HDAC inhibitors and new regimens from clinical trials for epigenetic therapy of cancer.

\section{Vorinostat (SAHA, Zolinza)}

Eighteen enzymes from HDAC family have been identified in human [4,11-14]. Voriniostat (formerly, suberoy- lanilide hydroxamine, SAHA) is a pan-HDAC inhibitor $[4,14]$. SAHA has significant anti-cancer activity in a wide range of cancers [4,14-17]. Vorinostat (VOR) was studied in a phase II trial for patients with refractory cutaneous Tcell lymphoma (CTCL) [4,15-18]. 33 patients who have failed a median of 5 prior therapies were enrolled. Similar to other epigenetic agents, time to response to SAHA was 11.9 weeks. SAHA is well tolerated orally with common toxicities including fatigue, thrombocytopenia, nausea and diarrhea. $200 \mathrm{mg}$ BID orally has the most favorable safety and efficacy profile [4,15-18]. A separate phase IIb trial which included 74 patients with refractory or persistent CTCL confirmed the activity of VOR $[19,20]$. 32\% of the patients also had pruritus symptom relief. Pulmonary embolism was reported in $5 \%$ of the patients. VOR has been approved for treatment of refractory CTCL (Zolinza, Merck). Since then there have been more than 30 trials testing VOR in single agent or in combination (Table 1 and 2). In an analysis reported at the American society of Clinical Oncology (ASCO) 2008 annual meeting, 476 patients received VOR either as single agent or combined 
Table I: Vorinostat in single agent trials

\begin{tabular}{|c|c|c|c|c|c|c|}
\hline $\mathrm{HDACl}$ & Disease & Dose \& schedule & Phase & No. Pts & Outcome & Reference \\
\hline Vorinostat & Various cancer & $400 \mathrm{mg}$, oral & 1 & 476 & Tolerated, safe & {$[21]$} \\
\hline Vorinostat & CTCL & 200 mg Bid PO & Ilb & 74 & $\begin{array}{l}\text { CR: } 16 \% \\
\text { PR: } 67 \% \\
\text { SD: } 16 \%\end{array}$ & {$[20]$} \\
\hline Vorinostat & Gl cancer & 300 mg Bid PO 3 days/w q2Id & II & 16 & safe, PK results & [26] \\
\hline Vorinostat & TCC & 200 mg Bid PO & II & 14 & study closed & [36] \\
\hline Vorinostat & Breast, colon, lung Cancer & $200-400 \mathrm{mg}$ Bid PO $\times 14 q 21 \mathrm{~d}$ & II & 16 & SD: $50 \%$ & {$[22]$} \\
\hline Vorinostat & MM & $\begin{array}{l}200-300 \mathrm{mg} \text { Bid } \mathrm{PO} \times 5 \mathrm{~d} / \mathrm{wq} 28 \mathrm{~d} / 200-400 \\
\mathrm{mg} \text { Bid } \mathrm{PO} \times \mathrm{I} \mathrm{d} / \mathrm{wq} 2 \mathrm{Id}\end{array}$ & 1 & 13 & No response & {$[40]$} \\
\hline Vorinostat & DLBCL & 300 mg Bid PO 3 days/week & II & 18 & $\begin{array}{l}\text { CR: } 5.5 \% \\
\text { SD: } 5.5 \%\end{array}$ & [23] \\
\hline Vorinostat & Gynecologic tumor & $400 \mathrm{mg} / \mathrm{d} \mathrm{PO}$ & II & 27 & Insufficient activity (PR: 3\%) & [37] \\
\hline Vorinostat & MDS, leukemia & $100-300 \mathrm{mg} \mathrm{Bid} / \mathrm{TidPO} \times 14 \mathrm{q} 21 \mathrm{~d}$ & 1 & 41 & MTD:200 mg Bid & {$[24]$} \\
\hline Vorinostat & Head neck cancer & $400 \mathrm{mg}$ qd PO & II & 12 & No response & {$[4 I]$} \\
\hline Vorinostat & mesothelioma & NR & 1 & 13 & PR: $15 \%$ & [35] \\
\hline
\end{tabular}

CR: complete responses; PR: partial response; SD: stable disease. MTD: maximal tolerated dose; NR: not reported.

Table 2: Vorinostat in combination trials

\begin{tabular}{|c|c|c|c|c|c|c|c|}
\hline $\mathrm{HDACl}$ & Other agent & Disease & Dosage & Phase & Pts No & Response & Reference \\
\hline Vorinostat & capecitabine & Solid tumors & $\begin{array}{l}\text { VOR:300-400 mg/d PO } \\
\text { CAP:750-1000 mg bid PO }\end{array}$ & 1 & 28 & $\begin{array}{l}\text { CR: } 3 \% \\
\text { PR: } 10 \% \\
\text { SD: } 64 \%\end{array}$ & [33] \\
\hline Vorinostat & bevacizumab & kidney cancer & $\begin{array}{l}\text { VOR: } 200 \mathrm{mg} \text { BID } \times 14 \mathrm{~d} P O \\
\text { BEV: } 15 \mathrm{mg} / \mathrm{kg}, \mathrm{q} 2 \mathrm{Idiv}\end{array}$ & 1 & 8 & SD: $42 \%$ & {$[27]$} \\
\hline Vorinostat & bexarotene & CTCL & $\begin{array}{l}\text { VOR:300-400 mgqdPOq28d } \\
\text { BEX:150-300 mg/m²qdq28d }\end{array}$ & 1 & 19 & $\begin{array}{l}\text { CR: } 5 \% \\
\text { PR: } 15 \% \\
\text { SD: } 63 \%\end{array}$ & {$[28]$} \\
\hline Vorinostat & tamoxifen & breast cancer & $\begin{array}{l}\text { VOR: } 400 \mathrm{mg} / \mathrm{d} \times 2 \text { Id } \mathrm{PO} \\
\text { T AM: } 20 \mathrm{mg} / \mathrm{d} \text { PO }\end{array}$ & II & 19 & $\begin{array}{l}\text { CR: } 5 \% \\
\text { PR: } 15 \%\end{array}$ & {$[32]$} \\
\hline Vorinostat & $\begin{array}{l}\text { Gemcitabine } \\
\text { Carboplatin/Cisplatin }\end{array}$ & NSCLC & $\begin{array}{l}\text { VOR:300-400 mgqdPOx7d } \\
\text { GEM: } 1000-1250 \mathrm{mg} / \mathrm{m}^{2}, \\
\text { ivd3, } 10 \\
\text { C BP:5.0AUC, iv/CDDP:75 } \\
\mathrm{mg} / \mathrm{m}^{2} \text {, iv d3 }\end{array}$ & 1 & 12 & $\begin{array}{l}\text { PR: } 57 \% \\
\text { SD: } 28 \%\end{array}$ & {$[38]$} \\
\hline Vorinostat & I3-cis-retinoid acid & $\begin{array}{l}\text { Pediatric CNS, } \\
\text { solid tumors }\end{array}$ & $\begin{array}{l}\text { VOR: } 180-230 \mathrm{mg} / \mathrm{m}^{2} \text { po qd } \\
\text { I3cRA: } 80 \mathrm{mg} / \mathrm{m}^{2} \text { po bid }\end{array}$ & 1 & 13 & $\begin{array}{l}\text { MTD: VOR } 180 \mathrm{mg} / \mathrm{m}^{2} / \mathrm{d} \times 4 / \mathrm{w} \\
\text { I3cRA: } 80 \mathrm{mg} / \mathrm{m}^{2} \mathrm{bid}\end{array}$ & [39] \\
\hline Vorinostat & Carboplatin Paclitaxel & solid tumors & $\begin{array}{l}\text { VOR: } 400-600 \mathrm{mg} / \mathrm{d} \text { PO } \\
\text { q2Id } \\
\text { C BP: } 6.0 \mathrm{AUC} \text {, iv } \\
\text { PTX: } 200 \mathrm{mg} / \mathrm{m}^{2} \text {, iv }\end{array}$ & 1 & 28 & $\begin{array}{l}\text { PR: } 44 \% \\
\text { SD: } 28 \%\end{array}$ & {$[34]$} \\
\hline Vorinostat & bortezomib & MM & $\begin{array}{l}\text { VOR: } 100-400 \mathrm{mg} \text { PO d4-II } \\
\text { VEL:I.3 mg/m² IV dI, 4, } 8 \\
\text { and II }\end{array}$ & 1 & 23 & $\begin{array}{l}\text { MTD: VOR } 400 \mathrm{mg} \mathrm{d} 4- \\
\text { I I;VELI.3 mg/m² } \mathrm{dl}, 4,8, \mathrm{I} \text {. }\end{array}$ & {$[25]$} \\
\hline
\end{tabular}

VEL: bortezomib; CR: complete responses; PR: partial response; SD: stable disease. MTD: maximal tolerated dose; 
with another agent [21]. More than half of those patients had fatigue, nausea and diarrhea. Dose modifications were not required nevertheless in the majority of the patients.

In a multicenter phase II single agent study, 16 patients with breast, colon and lung cancers received VOR at doses of 200,300, and $400 \mathrm{mg}$ BID for 14 days out of every 3 weeks. Disease stabilization was observed in half of the patients, but there were no confirmed responses [22].

In a single agent phase I study of VOR for patients with recurrent diffuse large B-cell lymphoma, 2 of the 18 enrolled patients had response, the other 16 had disease progression [23]. $300 \mathrm{mg}$ BID 3 days/week was well tolerated but with limited activity.

Single agent VOR was also investigated in a phase I study for patients with leukemia and myelodysplasia (MDS) [24]. Thirty one of the 41 patients enrolled had acute myeloid leukemia (AML). VOR was given twice or thrice daily for 14 days with dose range of $100-300 \mathrm{mg}$ in a 21-day cycle. The Maximal tolerated dose (MTD) was $200 \mathrm{mg}$ BID. Seven patients had hematological improvement, including 4 AML with complete responses. Increased histone acetylation was seen at all dose levels.

VOR was combined with bortezomib in a phase I trial for patients with relapsed or refractory multiple myeloma (MM) [25]. The dose limiting toxicity (DLT) was QT prolongation and fatigue. The MTD was VOR $400 \mathrm{mg}$ on days 4-11 and bortezomib $1.3 \mathrm{mg} / \mathrm{m}^{2}$ on day $1,4,8,11$.

In a phase I trial for Japanese patients with gastrointestinal cancer, DLT of single agent VOR was grade 4 thrombocytopenia [26]. In this group of 16 Japanese patients, 300 mg BID for 3 consecutive days followed by a 4-day rest each week was the tolerable regimen.

In a small phase I study of patients with stage IV renal cell carcinoma, VOR $200 \mathrm{mg}$ BID $\times 14$ days was combined with bevacizumab $15 \mathrm{mg} / \mathrm{kg}$ on a 21-day cycle [27]. Eight patients were enrolled. Severe thrombocytopenia was the DLT at the above dosing schedules (MTD). Phase II study is underway.

In a preliminary report of a phase I dose-escalating trial of VOR plus bexarotene for advanced CTCL, 19 patients were included [28]. MTD was not reached yet. 1 patient had a $\mathrm{CR}, 3$ had a PR, and 12 had stable disease.

HDAC inhibitors have been reported to restore hormone sensitivity of estrogen and progesterone receptors [29-31]. VOR $400 \mathrm{mg}$ daily $\times 3$ weeks was combined with daily tamoxifen in a 4-week cycle for patients with hormone- refractory breast cancer [32]. 17 of the 19 enrolled patients were evaluable. Four patients had objective response, one of them was in CR. $\mathrm{H} 3$ and $\mathrm{H} 4$ histone acetylation was seen at day 8 . These findings imply that VOR may restore hormone sensitivity in hormone-refractory breast cancer patients.

VOR was investigated in combination with capecitabine (CAP) in a phase I/II trial for patients with advanced solid tumors [33]. Twenty eight patients were in phase I, 14 patients were in phase II. The phase II regimen was VOR $300 \mathrm{mg}$ daily plus CAP $1000 \mathrm{mg}$ BID $\times 14$ days per 21 day cycle. Preliminary results appeared to be encouraging.

In another phase I trial for patients with advanced solid tumors, VOR was combined with carboplatin (AUC $=6$ ) and paclitaxel $\left(200 \mathrm{mg} / \mathrm{m}^{2}\right)$ [34]. VOR was given as 400 mg daily $\times 14$ days or $300 \mathrm{mg}$ BID $\times 7$ days in a 3-week cycle. Twenty five of the 28 patients enrolled were evaluable. The DLT was emesis and neutropenia. 11 patients had PR, 7 patients had stable disease. Both VOR dosing schedule was well tolerated in combination.

Advanced mesothelioma progressed after first-line chemotherapy has poor prognosis. thirteen such patients were included in a single agent phase I trial [35]. Two patients had a partial response. This was considered to be promising for these poor-prognostic patients. A randomized phase III trial of oral VOR for patients with advanced mesothelioma are underway.

VOR $200 \mathrm{mg}$ BID was also evaluated in a single agent phase II study for patients with recurrent/metastatic transitional cell carcinoma who failed platinum therapy [36]. Fourteen patients were included in the report at ASCO 2008 meeting. Two early on-study death was reported, and the study was closed to further accrual.

Single agent VOR at $400 \mathrm{mg}$ daily had disappointing results in a phase II study for patients with platinumresistant ovarian or primary peritoneal carcinoma [37]. VOR is also being studied in several phase I studies with a variety of regimens including gemcitabine/cisplatin for lung cancer, 13 cis-retinoic acid for children with solid tumors (Table 1 and 2) [38,39]. Final results are awaited. Single agent VOR for solid tumors and MM was overall disappointing in early clinical trials $[22,37,40,41]$.

\section{New HDAC inhibitors}

HDAC inhibitors generally consist of three parts in the chemical structure: (1) a zinc-chelating group; (2) a spacer group, which is generally hydrophobic; and (3) an "enzyme binding" group that confers specificity and is generally aromatic in character [42]. A spectrum of naturally occurring or synthetic HDAC inhibitors have been 
Table 3: New HDAC inhibitors in clinical trials

\begin{tabular}{|c|c|c|c|c|c|c|c|}
\hline $\mathrm{HDACl}$ & Other agents & Dose \& schedule & disease & Phase & Pts No & Outcome & Reference \\
\hline $\mathrm{Cl}-994$ & capecitabine & $4-6 \mathrm{mg} / \mathrm{m}^{2}$ & solid tumors & 1 & 54 & MTD:6 mg/m² & {$[49,50]$} \\
\hline Cl-994 & gemcitabine & $2-8 \mathrm{mg} / \mathrm{m}^{2}$ po qd & solid tumors & 1 & 20 & $\begin{array}{l}\text { MTD: } 6 \mathrm{mg} / \mathrm{m}^{2+} \\
\text { Gem } 1000 \mathrm{mg} / \mathrm{m}^{2}\end{array}$ & [47] \\
\hline $\mathrm{Cl}-994$ & paclitaxel carboplatin & $4-6 \mathrm{mg} / \mathrm{m}^{2}$ & solid tumors & 1 & 30 & MTD: 4 mg/m² & [48] \\
\hline $\mathrm{Cl}-994$ & & $8 \mathrm{mg} / \mathrm{m}^{2}$ po qd & solid tumors & $\mathrm{I} / \mathrm{II}$ & 53 & MTD:8 mg/m² & {$[46]$} \\
\hline FK228 & gemcitabine & $7-12 \mathrm{mg} / \mathrm{m}^{2}$ & Pancreatic, Solid tumors & 1 & 33 & $\begin{array}{l}\text { MTD: } 12 \mathrm{mg} / \mathrm{m}^{2+} \\
\text { Gem } 800 \mathrm{mg} / \mathrm{m}^{2}\end{array}$ & [53] \\
\hline FK228 & & $\mathrm{I}-9 \mathrm{mg} / \mathrm{m}^{2}$ & thyroid, Solid tumors & 1 & 26 & MTD: 9 mg/m² & {$[54]$} \\
\hline FK228 & & $18 \mathrm{mg} / \mathrm{m}^{2}$ i.v. dl \& d5, q3w & MDS, AML & II & 12 & $\begin{array}{l}\text { CR: } 8 \% \\
\text { SD: } 50 \%\end{array}$ & {$[55]$} \\
\hline FK228 & & $17.8 \mathrm{mg} / \mathrm{m}^{2} \mathrm{dl} \& \mathrm{~d} 7, \mathrm{q} 3 \mathrm{w}$ & lung cancer & II & 19 & No response & {$[56]$} \\
\hline FK228 & & $14 \mathrm{mg} / \mathrm{m}^{2}$ i.v.dI, $8,15 \mathrm{q} 4 \mathrm{w}$ & T-cell lymphoma & II & 42 & $\begin{array}{l}\text { no myocardial } \\
\text { damage }\end{array}$ & {$[58]$} \\
\hline FK228 & & $\begin{array}{l}13 \mathrm{mg} / \mathrm{m}^{2} \text { i.v.d I, 8, } 15 \\
\mathrm{q} 4 \mathrm{w}\end{array}$ & Kidney CA & II & 29 & $\begin{array}{l}\text { Insufficient activity } \\
\text { (7\% RR) }\end{array}$ & {$[57]$} \\
\hline ITF2357 & & $\begin{array}{l}150 \mathrm{mg} \text { or } 100 \mathrm{mgQ} / 2 \mathrm{~h} \\
4 \mathrm{~d}\end{array}$ & MM & II & 16 & PR: 6\% SD: $31 \%$ & {$[61]$} \\
\hline ITF2357 & & $100 \mathrm{mg} P O$ & Hodgkins & II & 15 & SD: $54 \%$ & {$[60]$} \\
\hline LBH589 & $\begin{array}{l}\text { Docetaxel } \\
\text { prednisone }\end{array}$ & I5-20 mg po qod & CRPC & 1 & 16 & $\begin{array}{l}\text { Oral study closed. } \\
\text { IV form ongoing }\end{array}$ & {$[64]$} \\
\hline LBH589 & & $20 \mathrm{mg}$ day I, 35 & CTCL & II & 40 & RR: $12 \%$ & {$[65]$} \\
\hline LBH589 & & $4.8-11.5 \mathrm{mg} / \mathrm{m}^{2} \mathrm{IV}$ & Hematological neoplasms & 1 & 15 & $\begin{array}{l}\text { Study halted due to } \\
\text { QTc prolongation }\end{array}$ & {$[63]$} \\
\hline MGCDOI03 & gemcitabine & $\begin{array}{l}\text { Phase I: } 50-110 \mathrm{mg} \\
\text { Phase II: } 90 \mathrm{mg}\end{array}$ & solid tumors & $\mathrm{I} / \mathrm{II}$ & 29 & MTD: 90 mg & [70] \\
\hline MGCDOI03 & & $12.5-56 \mathrm{mg} / \mathrm{m}^{2} / \mathrm{d}$ & solid tumors & 1 & 38 & MTD: 45 mg/m² & [68] \\
\hline MGCDOI03 & & $20-80 \mathrm{mg} / \mathrm{m}^{2}$ & leukemia & 1 & 29 & MTD: $60 \mathrm{mg} / \mathrm{m}^{2}$ & [69] \\
\hline MGCDOI03 & & $85 \mathrm{mg}, 110 \mathrm{mg}$ & $\mathrm{NHL}$ & II & 50 & RR: $23 \%$ & {$[7 I]$} \\
\hline MGCDOI03 & & $85 \mathrm{mg}, 110 \mathrm{mg}$ & $\mathrm{HL}$ & II & 33 & RR: $38 \%$ & [72] \\
\hline MS-275 & & $4-10 \mathrm{mg} / \mathrm{m}^{2}$ & leukemia & 1 & 38 & MTD:8 mg/m² & {$[75]$} \\
\hline MS-275 & & $4-6 \mathrm{mg} / \mathrm{m}^{2}$ & Solidtumors, lymphoma & 1 & 27 & MTD:6 mg/m² & {$[76]$} \\
\hline MS-275 & & $3-7 \mathrm{mg} / \mathrm{m}^{2}$ & melanoma & II & 28 & SD: $21-29 \%$ & {$[77]$} \\
\hline PCl-2478I & & $2.0-2.4 \mathrm{mg} / \mathrm{kg}$ & solid tumors & 1 & 15 & MTD: pending & [49] \\
\hline PBA & & $9-45 \mathrm{~g} / \mathrm{d}$ & solid tumors & 1 & 28 & MTD:27 g/day & {$[82]$} \\
\hline PBA & & $150-515 \mathrm{mg} / \mathrm{kg} / \mathrm{d}$ & solid tumors & 1 & 24 & MTD:410 mg/kg & {$[81]$} \\
\hline PBA & & $60 \mathrm{mg}-360 \mathrm{mg} / \mathrm{kg} / \mathrm{d}$ & solid tumors & 1 & 21 & MTD:300 mg/kg & {$[80]$} \\
\hline PBA & $5-\mathrm{FU}$ & $410 \mathrm{mg} / \mathrm{kg} / \mathrm{d}$ & colorectal cancer & 1 & 9 & MTD: Not reported & [83] \\
\hline PBA & azacitidine & $200 \mathrm{mg} / \mathrm{kg} / \mathrm{d}$ & AML MDS & II & 10 & RR:50\% & [84] \\
\hline PXDIOI & & $1000 \mathrm{mg} / \mathrm{m}^{2} / \mathrm{d} \times 5$ & Ovarian ca & II & 30 & SD: $60 \%$ & [88] \\
\hline PXDIOI & & $600,900,1000 \mathrm{mg} / \mathrm{m}^{2} /$ day & Hematological neoplasms & 1 & 16 & MTD: $1000 \mathrm{mg} / \mathrm{m}^{2} / \mathrm{day}$ & {$[87]$} \\
\hline PXDIOI & & $150-1200 \mathrm{mg} / \mathrm{m}^{2} /$ day & solid tumors & 1 & 46 & MTD: $1000 \mathrm{mg} / \mathrm{m}^{2} / \mathrm{day}$ & [86] \\
\hline VPA & & $\begin{array}{l}30-120 \mathrm{mg} \mathrm{kg}(-1) \operatorname{day}(-1) \\
\mathrm{IV} \times 5\end{array}$ & solid tumors & 1 & 26 & MTD: $60 \mathrm{mg} / \mathrm{kg} / \mathrm{day}$ & [93] \\
\hline VPA & ATRA & $\begin{array}{l}\text { serum level } 50-100 \mathrm{mcg} / \\
\mathrm{ml}\end{array}$ & AML & II & 58 & RR: $5 \%$ (not active) & [90] \\
\hline VPA & ATRA & $5-10 \mathrm{mg} / \mathrm{kg}$ & AML & I & 26 & Insufficient activity & [91] \\
\hline VPA & & $20-40 \mathrm{mg} / \mathrm{kg} / \mathrm{d} \times 5$ & Cervical ca & 1 & 12 & MTD: Not reported & {$[92]$} \\
\hline
\end{tabular}

HDAC: histone deacetylase inhibitor; CR: complete responses; PR: partial response; SD: stable disease. MTD: maximal tolerated dose; RR: response rate 
characterized for their antitumor activities in preclinical studies [43]. Six major classes of HDAC inhibitors have been defined on the chemical structures [44]. These include short-chain fatty acids (butyrate and valproic acid), hydroxamates (SAHA, trichostatin A, ITF2357, LBH589, oxamflatin, PCI-24781, and PXD101), benzamides (MS-275, CI-994, and MGCD-0103), cyclic tetrapeptides (depsipeptide, trapoxin A, and apicidin), electrophilic ketones (trifluoromethylketone), and miscellaneous (depudecin, SNDX-275, and isothiocyanates). In addition to vorinostat which has been approved for clinical treatment of advanced CTCL, there are at least 11 more HDAC inhibitors in various stages of clinical development (Table 3).

\section{Cl-994 (N-acetyldinaline, [4-(acetylamino)-N-(2-amino-phenyl) benzamide])}

CI-994 is an orally active HDAC inhibitor that belongs to the benzamide class [45]. A phase I/II study was carried out in patients with solid tumors. Fifty three patients received CI-994 orally for 2-10 weeks [46]. Thrombocytopenia was the DLT. The MTD was $8 \mathrm{mg} / \mathrm{m}^{2} /$ day for 8 weeks. One refractory lung cancer patient had PR for over 2 years, 3 additional patients had stable disease.

CI-994 was investigated in combination with gemcitabine in a phase I trial for solid tumors [47]. Twenty patients were treated with gemcitabine $\left(1000 \mathrm{mg} / \mathrm{m}^{2}\right.$ on days 1,8 , 15). CI-994 was given orally in a dose-escalating schedule from 2-8 $\mathrm{mg} / \mathrm{m}^{2} /$ day in a 21 -day cycle. The DLT was thrombocytopenia, and the MTD was $6 \mathrm{mg} / \mathrm{m}^{2}$ for combination with gemcitabine. CI-994 was also studied in combination with paclitaxel and carboplatin in a phase I trial in patients with advanced solid tumors [48]. CI-994 dose ranged $4-6 \mathrm{mg} / \mathrm{m}^{2}$ for one or two weeks. Thirty patients were enrolled. The MTD was $4 \mathrm{mg} / \mathrm{m}^{2}$ for 7 days for the combination regimen. CI-994 was evaluated in another phase I trial in combination with capecitabine $[49,50]$. Fifty four patients with advanced solid tumors were enrolled. CI-994 was given in a dose-escalating schedule from $4-6 \mathrm{mg} / \mathrm{m}^{2}$ daily. The DLT was thrombocytopenia. The MTD was $6 \mathrm{mg} / \mathrm{m}^{2}$ daily for two weeks in a 21-day cycle in combination with capecitabine.

\section{FK228 (FR901228, depsipeptide, romidepsin)}

FK 228 is a potent bicyclic depsipeptide and a novel HDAC inhibitor $[51,52]$.

FK228 was studied in combination with gemcitabine in a phase I trial for patients with advanced solid tumors [53]. Thirty three patients were included in the report. Nonhematologic toxicities have been mild to moderate nausea, vomiting, and fatigue. The recommended phase II dose schedule is FK228 (romidepsin) $12 \mathrm{mg} / \mathrm{m}^{2}$ and gemcitabine $800 \mathrm{mg} / \mathrm{m}^{2}$ every other week.
HDAC inhibitors restore expression of the sodium iodine symporter in refractory cells and sensitivity to RAI in vitro. A phase I trial was conducted for patients with thyroid and other advanced cancers using FK228 (romidepsin) on days 1, 3, 5 [54]. Twenty six patients were enrolled. Severe adverse events were hematologic and GI toxicities. The MTD is $9 \mathrm{mg} / \mathrm{m}^{2}$. Histone acetylation was shown to have a greater than 2-fold increase. This study was planned to focus exclusively on non-medullary thyroid cancer.

FK228 (depsipeptide) was also evaluated in a phase II study for patients with high risk MDS and AML [55]. FK228 was given on day 1 and day 8 to 12 patients at 18 $\mathrm{mg} / \mathrm{m}^{2}$ over a 4 -hour infusion every 3 weeks. There was one CR, six stable diseases. Histone H3 and H4 acetylation was seen, but there was no consistent changes.

Another phase II trial of FK228 was done in patients with refractory lung cancer [56]. Nineteen patients were treated on day 1 and 7 every 3 weeks at a dose of $17.8 \mathrm{mg} / \mathrm{m}^{2}$. Hematologic toxicity was dose-limiting in one patient, no objective responses were observed in this single agent study.

In another single-agent phase II trial, FK228 was given to patients with refractory metastatic renal cell carcinoma at $13 \mathrm{mg} / \mathrm{m}^{2}$ on days 1,8 , and 15 of a 28-day cycle [57]. Twenty nine patients were enrolled. Four patients had severe cardiac toxicity with one sudden death. There was only a $7 \%$ overall response rate. The study was closed due to insufficient efficacy. In a separate study with detailed monitoring of cardiac toxicities in 42 patients with T-cell lymphoma, Fk228 was given at $14 \mathrm{mg} / \mathrm{m}^{2}$ on days 1,8 , and 15 of a 28-day cycle [58]. FK228 was not found to be associated with myocardial damage or decrease in cardiac function even though EKG changes with T-wave flattening or ST-segment depression were observed. The cardiac toxicities are believed to be a class effect of HDAC inhibitors.

\section{ITF2357}

ITF2357 is an orally effective member of hydroxamic family of HDAC inhibitors and can reduce production of inflammatory cytokines [59]. ITF2357 was investigated in an Italian phase II trial on patients with heavily pretreated refractory Hodgkin's disease [60]. ITF2357 was given at $100 \mathrm{mg}$ PO daily. Fifteen patients were enrolled, 13 were evaluable for responses. Stable diseases were seen in seven (54\%) patients. $20 \%$ of the patients had QTc interval prolongation prompting transient drug discontinuation. Overall it was reported to be well tolerated.

A phase II study reported at ASH 2007 annual meeting administered $150 \mathrm{mg}$ or $100 \mathrm{mg}$ of ITF2357 orally every 12 hours for four consecutive days followed by a 3 day rest every week of a 28-day cycle [61]. Sixteen patients with 
refractory MM were treated. The most common grade 3-4 toxicities were GI side effects, neutropenia, and thrombocytopenia. Three patients had abnormal EKG changes. One patient achieved partial response, and five others had stable diseases.

\section{4. $\mathrm{LBH} 589$ (panobinostat)}

LBH589 is a novel pan-HDAC inhibitor. Treatment with LBH589 not only has been shown to induce acetylation of histones, induction of p21, cell cycle growth arrest, and apoptosis but also has been demonstrated to induce acetylation of HSP90 [62].

LBH589 IV formulation was investigated in a phase I trial for patients with refractory hematological malignancies [63]. LBH589 as a single agent was administered as a 30minute i.v. infusion once daily on days 1 to 7 of a 21-day cycle. The doses ranged from $4.8 \mathrm{mg} / \mathrm{m}^{2}$ to $14 \mathrm{mg} / \mathrm{m}^{2} .15$ patients were enrolled. The DLT was QTc prolongation at $14 \mathrm{mg} / \mathrm{m}^{2}$. A significant increase in acetylation of the $\mathrm{H} 2 \mathrm{~B}$ and $\mathrm{H} 3$ histones in the leukemic blast $\left(\mathrm{CD} 34^{+}\right)$cells is consistent with LBH589 reaching its target. The study was halted due to safety concerns about QTc prolongation.

Oral LBH589 was studied alone and in combination with docetaxel and prednisone in castration-resistant prostate cancer [64]. $20 \mathrm{mg}$ of oral LBH589 was administered on days 1, 3 and 5 for 2-week on and 1-week off schedule for LBH589 alone arm, $15 \mathrm{mg}$ of LBH589 was given following the same schedule in the combination arm. Eight patients were enrolled into each arm. There was no apparent synergistic effect in the combination arm. Three patients achieved PR as the best responses. This study was closed and further clinical trials are being focused on IV formulation which produces higher peak concentration with comparable toxicity profile.

LBH589 was tested in a phase II trial in patients with CTCL [65]. LBH589 was administered orally at $20 \mathrm{mg}$ on days 1,3 , and 5 weekly until disease progression. Patients with cardiovascular abnormalities or QTc $>450 \mathrm{msec}$ were excluded. Intensive ECG monitoring was performed. 40 patients have been enrolled in the report. Five patients achieved skin response including one complete skin response. Another patient with $\mathrm{PD}$ improved to PR after initial flaring of disease. There was no QTc>500 ms observed.

\section{MGCDOIO3}

MGCD0103 is a selective orally available benzamide HDAC inhibitor that targets HDAC 1, 2, 3 (class 1) and 11 (class 4) [66,67]. It avoids the class 2 enzymes.

MGCD0103 was studied in a phase I trial for patients with advanced solid tumors. It was administered orally three- times-per-week for 2 of every 3 weeks [68]. The dose ranges were from $12.5 \mathrm{mg}$ to $56 \mathrm{mg} / \mathrm{m}^{2}$ in 38 patients over 99 cycles. The DLT included fatigue, nausea, vomiting, and diarrhea. The recommended phase II dose was $45 \mathrm{mg} /$ $\mathrm{m}^{2} /$ day. There was inhibition of HDAC activity and induction of acetylation of H3 histones by MGCD0103.

A separate phase 1 trial of oral MGCD0103 was conducted in patients with leukemia and myelodysplastic syndromes [69]. MGCD0103 was administered orally 3 times weekly without interruption. Twenty-nine patients with a median age of 62 years (32-84 years) were enrolled at dose levels of $20-80 \mathrm{mg} / \mathrm{m}^{2}$. The DLT were similar to those reported from the previous study [68]. The maximum tolerated dose was determined to be $60 \mathrm{mg} / \mathrm{m}^{2}$. Three patients achieved a complete bone marrow response.

MGCD0103 was also evaluated in a phase I/II trial in combination with gemcitabine in patients with solid tumors [70]. Twenty-nine patients were enrolled (25 in phase I, 4 in phase II). Dose levels of MGCD0103 ranged between 50 and $110 \mathrm{mg}$. The MTD and recommended phase II dose was $90 \mathrm{mg}$. 2 of 5 pancreatic cancer patients achieved PR. Phase II at $90 \mathrm{mg}$ MGCD0103 $3 \times$ /week plus gemcitabine $100 \mathrm{mg} / \mathrm{m}^{2}$ weekly $\times 3$ per 4 -week cycle is ongoing for pancreatic cancer patients.

A phase II trial of oral MGCD0103 was conducted in patients with refractory large B-cell (DLBCL) or follicular lymphoma [71]. Among 50 patients enrolled, 32 patients received $110 \mathrm{mg}$ three times per week. The dose was reduced to $85 \mathrm{mg} 3 \times$ /week afterwards. $1 \mathrm{CR}$ and 3 PRs with a response rate of $23.5 \%$ were achieved in 17 patients with DLBCL. Inhibition of HDAC activity was seen in 13 of 18 patients evaluated. In a separate phase II study, patients with refractory Hodgkin lymphoma were enrolled for treatment with MGCD0103 [72]. Twenty three patients received $110 \mathrm{mg}, 10$ patients had $85 \mathrm{mg} 3$ $\times$ /week in 4 -week cycles. Most patients had failed prior autologous transplants. Among the $110 \mathrm{mg}$ cohorts, 2 patients achieved CR, 6 achieved PR, for an overall response rate of $38 \%$. The median time to response was 2 cycles. The $85 \mathrm{mg}$ dose was better tolerated and further study at this dose level is ongoing.

\section{MS-275 (MS-27-275; N-(2-aminophenyl)-4-[N-(pyridin-3-yl- methoxycarbonyl) aminomethyl] benzamide)}

MS-275 is a novel synthetic benzamide derivative that has been shown to inhibit HDAC activity $[73,74]$. A phase I dose-escalating study has been completed in patients with advanced acute leukemia [75]. Thirty eight patients were enrolled. The first 13 patients were treated with MS-275 initially once weekly $\times 2$, repeated every 4 weeks from 4 to $8 \mathrm{mg} / \mathrm{m}^{2}$. The rest of the patients were treated once weekly $\times 4$, repeated every 6 weeks from 8 to $10 \mathrm{mg} / \mathrm{m}^{2}$. The MTD 
was $8 \mathrm{mg} / \mathrm{m}^{2}$ weekly for 4 weeks in 6-week cycle. The DLTs included infections and neurologic toxicity manifesting as unsteady gait and somnolence. MS-275 induced H3 and H4 acetylation.

MS-275 was also investigated in patients with solid tumors in a phase I trial [76]. Twenty seven patients with advanced solid malignancies and lymphomas were treated on three dose schedules. MS-275 is well tolerated at doses up to $6 \mathrm{mg} / \mathrm{m}^{2}$ every other week or $4 \mathrm{mg} / \mathrm{m}^{2}$ weekly for 3 weeks. The DLTs were hypophosphatemia and asthenia on the weekly and twice-weekly dosing schedules; there was no dose-limiting toxicity on the every other week schedule. Four $\mathrm{mg} / \mathrm{m}^{2}$ given weekly for 3 weeks every 28 days were recommended for phase II study.

A phase II trial was done on patients with refractory metastatic melanoma [77]. Twenty eight patients were randomized to receive MS-275 $3 \mathrm{mg}$ biweekly (days $1+15$, arm A) or 7 mg weekly (days $1+8+15$, arm B), in 4-week cycles. Nausea and hypophosphatemia were the most common toxicities. No objective response was reported. Stable disease was observed (29\% in Arm A, 21\% in Arm B). Single agent MS-275 appears to be ineffective in this population of patients.

\section{7. $\mathrm{PCl}-2478 \mathrm{I}$ (CRA-02478I)}

PCI-24781 is a novel, broad spectrum hydroxamate-based inhibitor of HDAC that shows preclinical antitumor activity [78]. A phase I study was done in patients with solid tumors [49]. 15 patients were reported at the ASCO 2008 annual meeting. Intravenous and oral forms are both studied. Tubulin and histone acetylation were measured in peripheral blood mononuclear cells. Hematologic and GI toxicities were observed, and 1 patient had EKG changes. Acetylation levels increased at 1.5 hour post dose and sustained through 4 hours in all patients and up to 24 hours in $60 \%$ of the patients. PCI-24781 was well tolerated following IV administration. Further study of oral formulation is ongoing.

\section{Phenylbutyrate}

Phenylbutyrate (PBA) is an aromatic short-chain fatty acid that has activity in HDAC inhibition [79]. Phase I clinical studies have been done [80-82]. Oral PBA was evaluated in a phase I trial [82]. Twenty eight patients with refractory solid tumors were included. Five dose levels ( $9 \mathrm{gm} /$ day to $36 \mathrm{gm} /$ day in three divided doses) were studied. The DLTs were nausea, vomiting and hypocalcemia at $36 \mathrm{gm} / \mathrm{day}$. $27 \mathrm{gm} /$ day was the recommended phase II dose. PBA was administered intravenously as 120-hour infusion in 24 patients with solid tumors in a separate phase I trial [81]. Six dose levels were studied (150 mg to $515 \mathrm{mg} / \mathrm{kg} /$ day in 21-day cycles). The DLTs were mainly neurological, such as somnolence and confusion. The MTD was $410 \mathrm{mg} / \mathrm{kg} /$ day for 5 days. Another phase I trial evaluated twice-daily PBA infusions for two consecutive weeks every month at five doses levels ( $60 \mathrm{mg}-360 \mathrm{mg} / \mathrm{kg} /$ day) in patients with advanced solid tumors [80]. The MTD was $300 \mathrm{mg} / \mathrm{kg} /$ day.

PBA was also studied in combination with 5-fluouracil (FU) in a phase I trial. FU (24-hour continuous intravenous infusion (CIV)) with dose escalation $\left(2-2.3 \mathrm{~g} / \mathrm{m}^{2}\right)$, in combination with PB (120 hour CIV at fixed dose 410 $\mathrm{mg} / \mathrm{kg} / \mathrm{d} \times 5)$ was administered weekly in patients with advanced colorectal cancer [83]. Nine patients were enrolled. MTD has not been reached at the time of report. PBA was also combined with azacitidine in a phase II trial for patients with AML and MDS [84] (see above under section of azacitidine).

\section{PXDI0I (belinostat)}

PXD101 is a novel hydroxamate-type HDAC inhibitor $[43,85]$. A phase I trial of PXD101 was performed on patients with advanced solid tumors [86]. Forty six patients were enrolled. 6 dose levels were tested. The DLT were grade 3 fatigue. The MTD was determined to be 1000 $\mathrm{mg} / \mathrm{m}^{2} \mathrm{IV}$ infusion over 30 minutes daily for 5 days per 21-day cycle. Histone H4 hyperacetylation was observed after each infusion and was sustained for 4 to 24 hours in a dose-dependent manner. Of the patients treated at the MTD, 50\% achieved stable disease.

Another phase I dose-finding study was done in patients with advanced hematological malignancies [87]. Sixteen patients were enrolled. Four dose levels were included. One patient developed drug-related grade 3 toxicities, including fatigue and neurological symptoms. The MTD was same as above and was to be used for phase II studies.

One phase II study of PXD101 was reported at 2008 ASCO annual meeting [88]. In this study, 30 patients with metastatic or recurrent and refractory ovarian cancer were enrolled. Eighteen out of the 30 patients had stable diseases. The study appears to be promising, and recruitment was still ongoing.

\section{Valproic acid}

Valproic acid (VPA, 2-propylpentanoic acid) is a well established drug for the therapy of epilepsy. It is teratogenic when administered during early pregnancy and can induce birth defects such as neural tube closure defects and other malformations. The well-tolerated antiepileptic drug was found to be a powerful HDAC inhibitor. VPA induces differentiation of carcinoma cells, transformed hematopoietic progenitor cells and leukemic blasts from acute myeloid leukemia patients [89]. 
VPA was studied in combination with All-trans retinoid acid (ATRA) in patients with AML who were not candidates for intensive chemotherapy [90]. Fifty eight patients were enrolled. Forty patients received the combination therapy. There was only $5 \%$ response rate for this group of patients with no CR observed. Another trial of VPA (5-10 $\mathrm{mg} / \mathrm{kg}$ ) plus ATRA $\left(45 \mathrm{mg} / \mathrm{m}^{2}\right)$ was done on 26 patients with poor-risk AML [91]. No patients achieved CR. These studies suggest that additional trials are needed to clearly define the activity of VPA in poor-risk AML patients.

A phase I trial of single agent VPA was reported in patients with newly diagnosed cervical cancer [92]. Twelve patients were included. VPA doses ranged from $20 \mathrm{mg} / \mathrm{kg}$ to 40 $\mathrm{mg} / \mathrm{kg}$ daily for 5 days. The most common side effect was depressed level of consciousness which was not severe. Tumor HDAC activity decreased in 8 patients. However, there was no correlation between $\mathrm{H} 3$ and $\mathrm{H} 4$ hyperacetylation with serum levels of VPA.

VPA was studied for IV administration in a phase I trial for patients with advanced cancer [93]. Twenty six patients were enrolled. VPA was administered as a 1-hour infusion daily for 5 consecutive days in a 21-day cycle with doses ranging between $30 \mathrm{mg} / \mathrm{kg} /$ day and $12 \mathrm{mg} / \mathrm{kg} /$ day. The MTD was $60 \mathrm{mg} / \mathrm{kg} / \mathrm{day}$. The DLT was grade 3 or 4 neurological impairment occurring in 8 out of 26 patients.

\section{Other HDAC inhibitors in early stage of clinical development (Isothiocyanates, NVP-LAQ824, SNDX-275)}

Isothiocyanates (ITC) can be found as thioglucoside conjugates, i.e. glucosinolates, in a wide variety of cruciferous vegetables including broccoli, cabbages, watercress, and Brussel's sprouts, etc. A phase I study of glucosinolate and ITCs (sulforaphane) were done in healthy volunteers [94]. The excretion of a metabolite, dithiocarbamates, was measured. No clinically significant toxicities were observed. Sulforaphane and phenylhexyl isothiocyanate (PHI) are among the synthetic isothiocyanates that are shown to be HDAC inhibitors and have antitumor activities in vitro and in vivo [95-100]. PHI was found recently to have dual epigenetic effects as both HDAC inhibitor and hypomethylating agent [97]. Clinical development of ITCs is underway.

NVP-LAQ824 ((2E)-N-hydroxy-3-[4-[[(2-hydroxyethyl)[2-(1H-indol-3-yl)ethyl]aminolmethyl]phenyl]-2-

propenamide) is a structurally novel hydroxamate derivative of HDAC inhibitors $[101,102]$. It has broad antitumor activity in preclinical studies [103-106]. Clinical trials in human are currently underway.

SNDX-275 is another novel HDAC inhibitor and is currently undergoing a phase I trial in combination with azaciditine (see above under section of azacitidine).
There are more structurally novel HDAC inhibitors which have been shown to have preclinical antitumor activities [43]. Clinical developments are yet to be done.

\section{Conclusion}

Vorinostat is the first HDAC inhibitor that has been approved for treatment of CTCL. More than 11 HDAC inhibitors are in various stages of clinical development. HDAC inhibitors may have more potential in the combination therapy of a wide range of malignancies. Combination of novel epigenetic agents, including hypomethylating agents and HDAC inhibitors, and chemotherapeutic agents are being extensively investigated for clinical treatment of malignant disorders. Results from the clinical trials are eagerly awaited and being closed watched.

\section{Competing interests}

The authors declare that they have no competing interests.

\section{Authors' contributions}

SC and DL are involved in concept design. All authors participated in data collection, drafting and critically revising the manuscript.

\section{Acknowledgements}

Shundong Cang and Yuehua Ma are CAHON (CAHON.ORG) Research Scholars and recipients of fellowship grants from the International Scholar Exchange Foundation. This work was partly supported by New York Medical College Blood Diseases Fund.

\section{References}

I. Yoo CB, Jones PA: Epigenetic therapy of cancer: past, present and future. Nat Rev Drug Discov 2006, 5:37-50.

2. Hashimshony T, Zhang J, Keshet I, Bustin M, Cedar H: The role of DNA methylation in setting up chromatin structure during development. Nature Genet 2003, 34:187-192.

3. Cang S, Liu DL: Clinical advances in hypomethylating agents for epigenetic therapy of cancer. Current Cancer Drug Targets submitted and under review 2009.

4. Marks PA: Discovery and development of SAHA as an anticancer agent. Oncogene 2007, 26:135I-1356.

5. Marks PA, Dokmanovic M: Histone deacetylase inhibitors: discovery and development as anticancer agents. Expert Opin Investig Drugs 2005, I 4: I 497-I5II.

6. Xu WS, Parmigiani RB, Marks PA: Histone deacetylase inhibitors: molecular mechanisms of action. Oncogene 2007, 26:554I-5552.

7. Silverman LR, Demakos EP, Peterson BL, Kornblith AB, Holland JC, Odchimar-Reissig R, et al.: Randomized controlled trial of azacitidine in patients with the myelodysplastic syndrome: a study of the cancer and leukemia group B. J Clin Oncol 2002, 20:2429-2440.

8. Jabbour E, Issa JP, Garcia-Manero G, Kantarjian H: Evolution of decitabine development: accomplishments, ongoing investigations, and future strategies. Cancer 2008, I I 2:234 I-235 I.

9. Kantarjian H, Issa JP, Rosenfeld CS, Bennett JM, Albitar M, DiPersio J, et al:: Decitabine improves patient outcomes in myelodysplastic syndromes: results of a phase III randomized study. Cancer 2006, 106:1794-1803.

10. Kantariian H, Oki Y, Garcia-Manero G, Huang X, O'brien S, Cortes J, et al: Results of a randomized study of 3 schedules of lowdose decitabine in higher-risk myelodysplastic syndrome and chronic myelomonocytic leukemia. Blood 2007, 109:52-57.

II. Dokmanovic M, Marks PA: Prospects: histone deacetylase inhibitors. I Cell Biochem 2005, 96:293-304. 
12. Dokmanovic M, Perez G, Xu W, Ngo L, Clarke C, Parmigiani RB, et al.: Histone deacetylase inhibitors selectively suppress expression of HDAC7. Mol Cancer Ther 2007, 6:2525-2534.

13. Dokmanovic M, Clarke C, Marks PA: Histone deacetylase inhibitors: overview and perspectives. Mol Cancer Res 2007, 5:98I-989.

14. Raj K, John A, Ho A, Chronis C, Khan S, Samuel J, et al.: CDKN2B methylation status and isolated chromosome 7 abnormalities predict responses to treatment with 5 -azacytidine. Leukemia 2007, 21:1937-1944.

15. Kelly WK, Richon VM, O'Connor O, Curley T, Gregor-Curtelli B, Tong W, et al: Phase I clinical trial of histone deacetylase inhibitor: suberoylanilide hydroxamic acid administered intravenously. Clin Cancer Res 2003, 9:3578-3588.

16. Kelly WK, Marks PA: Drug insight: Histone deacetylase inhibitors - development of the new targeted anticancer agent suberoylanilide hydroxamic acid. Nat Clin Pract Oncol 2005 2:150-157.

17. Kelly WK, O'Connor OA, Krug LM, Chiao JH, Heaney M, Curley T, et al.: Phase I study of an oral histone deacetylase inhibitor, suberoylanilide hydroxamic acid, in patients with advanced cancer. J Clin Oncol 2005, 23:3923-3931.

18. Duvic M, Talpur R, Ni X, Zhang C, Hazarika P, Kelly C, et al.: Phase 2 trial of oral vorinostat (suberoylanilide hydroxamic acid, SAHA) for refractory cutaneous T-cell lymphoma (CTCL). Blood 2007, 109:31-39.

19. Olsen EA, Kim YH, Kuzel TM, Pacheco TR, Foss FM, Parker S, et al: Phase IIb multicenter trial of vorinostat in patients with persistent, progressive, or treatment refractory cutaneous $\mathrm{T}$. cell lymphoma. J Clin Oncol 2007, 25:3 I09-3II5.

20. Olsen EA, Duvic M, Breneman D, Pacheco TR, Parker S, Vonderheid $\mathrm{EC}$, et al.: Vorinostat provides prolonged safety and clinical benefit to patients with advanced cutaneous t-cell lymphoma (CTCL). J Clin Oncol 2008, 26:

21. Siegel DS, Hussein MA, Belani CP, Robert F, Rizvi S, Wigginton J, et al.: Safety and tolerability of vorinostat - Experience from the vorinostat clinical trial program. J Clin Oncol 2008, 26:

22. Vansteenkiste J, Van CE, Dumez H, Chen C, Ricker JL, Randolph SS, et al: Early phase II trial of oral vorinostat in relapsed or refractory breast, colorectal, or non-small cell lung cancer. Invest New Drugs 2008, 26:483-488.

23. Crump M, Coiffier B, Jacobsen ED, Sun L, Ricker JL, Xie H, et al. Phase II trial of oral vorinostat (suberoylanilide hydroxamic acid) in relapsed diffuse large-B-cell lymphoma. Ann Oncol 2008, 19:964-969.

24. Garcia-Manero G, Yang H, Bueso-Ramos C, Ferrajoli A, Cortes J, Wierda WG, et al.: Phase I study of the histone deacetylase inhibitor vorinostat (suberoylanilide hydroxamic acid [SAHA]) in patients with advanced leukemias and myelodysplastic syndromes. Blood 2008, I I I: 1060-1066.

25. Badros AZ, Philip S, Niesvizk R, Goloubeva O, Harris C, Zweibel J, et al.: Phase I trial of vorinostat plus bortezomib (bort) in relapsed/refractory multiple myeloma $(\mathrm{mm})$ patients $(\mathrm{pts})$. Clin Oncol [Proc Am Soc Clin Oncol] 2008, 26:. abst \# 8548. Ref Type: Journal (Full)

26. Chin K, Hatake K, Hamaguchi T, Shirao K, Doi T, Noguchi K, et al: A phase I study of vorinostat (suberoylanilide hydroxamic acid, SAHA) in Japanese patients with gastrointestinal (GI) cancer. J Clin Oncol 2008, 26:.

27. Hammers HJ, Verheul H, Wilky B, Salumbides B, Holleran J, Egorin MJ, et al:: Phase I safety and pharmacokinetic/pharmacodynamic results of the histone deacetylase inhibitor vorinostat in combination with bevacizumab in patients with kidney cancer. I Clin Oncol 2008, 26:.

28. Hymes K, Dummer R, Sterry W, Steinhoff M, Assaf C, Kerl H, et al:: Phase I trial of oral vorinostat in combination with bexarotene in patients with advanced cutaneous T-cell lymphoma. J Clin Oncol 2008, 26:.

29. Fan J, Yin WJ, Lu JS, Wang L, Wu J, Wu FY, et al.: ERalpha negative breast cancer cells restore response to endocrine therapy by combination treatment with both HDAC inhibitor and DNMT inhibitor. I Cancer Res Clin Oncol 2008, 134:883-890.

30. Jang ER, Lim SJ, Lee ES, Jeong G, Kim TY, Bang YJ, et al.: The histone deacetylase inhibitor trichostatin $A$ sensitizes estrogen receptor alpha-negative breast cancer cells to tamoxifen. Oncogene 2004, 23: I724-1736.
31. Keen JC, Yan L, Mack KM, Pettit C, Smith D, Sharma D, et al.: A novel histone deacetylase inhibitor, scriptaid, enhances expression of functional estrogen receptor alpha (ER) in ER negative human breast cancer cells in combination with 5-aza 2'deoxycytidine. Breast Cancer Res Treat 2003, 81:177-186.

32. Munster PN, Lacevic M, Schmitt M, Bicaku E, Marchion D, Stephens $A$, et al.: Phase II trial of vorinostat, a histone deacetylase inhibitor to restore the hormone sensitivity to the antiestrogen tamoxifen in patients with advanced breast cancer having failed prior aromatase inhibitor therapy. J Clin Oncol. 2008, 26(36):5896-5903

33. Townsley C, Oza AM, Tang P, Siu LL, Pond GR, Sarveswaran P, et al: Expanded phase I study of vorinostat (VOR) in combination with capecitabine (CAP) in patients (pts) with advanced solid tumors. J Clin Oncol J Clin Oncol. 2008 Mar 10;26(8):I324-30. 2008, 26(8): 1324-1330.

34. Ramalingam SS, Parise RA, Ramanathan RK, Lagattuta TF, Musguire LA, Stoller RG, et al:: Phase I and pharmacokinetic study of vorinostat, a histone deacetylase inhibitor, in combination with carboplatin and paclitaxel for advanced solid malignancies. Clin Cancer Res 2007, 13:3605-36I0.

35. Krug LM, Curley T, Schwartz L, Richardson S, Marks P, Chiao J, et al.: Potential role of histone deacetylase inhibitors in mesothelioma: clinical experience with suberoylanilide hydroxamic acid. Clin Lung Cancer 2006, 7:257-26I.

36. Cheung EM, Quinn DI, Tsao-Wei DD, Groshen SG, Aparicio AM, Twardowski P, et al:: Phase II study of vorinostat (Suberoylanilide Hydroxamic Acid, SAHA) in patients with advanced transitional cell urothelial cancer (TCC) after platinumbased therapy - California Cancer Consortium/University of Pittsburgh NCl/CTEP-sponsored trial. I Clin Oncol 2008, 26:.

37. Modesitt SC, Sill M, Hoffman JS, Bender DP: A phase II study of vorinostat in the treatment of persistent or recurrent epithelial ovarian or primary peritoneal carcinoma: a Gynecologic Oncology Group study. Gynecol Oncol 2008, 109:182-186.

38. Misset J, Tredaniel J, Descourt R, Morot-Sibilot D, Zalcman G, Gachard $\mathrm{E}$, et al.: Vorinostat in combination with gemcitabine plus platinum in patients with advanced non-small-cell lung cancer: A phase I, dose-escalation study. J Clin Oncol 2008, 26:

39. Fouladi M, Park JR, Sun J, Ingle AM, Ames MM, Stewart CF, et al.: A phase I trial and pharmacokinetic (PK) study of vorinostat (SAHA) in combination with 13 cis-retinoic acid (I3cRA) in children with refractory neuroblastomas, medulloblastomas, primitive neuroectodermal tumors (PNETs), and atypical teratoid rhabdoid tumor. I Clin Oncol 2008, 26:

40. Richardson P, Mitsiades C, Colson K, Reilly E, McBride L, Chiao J, et al.: Phase I trial of oral vorinostat (suberoylanilide hydroxamic acid, SAHA) in patients with advanced multiple myeloma. Leuk Lymphoma 2008, 49:502-507.

4I. Blumenschein GR Jr, Kies MS, Papadimitrakopoulou VA, Lu C, Kumar AJ, Ricker JL, et al.: Phase II trial of the histone deacetylase inhibitor vorinostat (Zolinza, suberoylanilide hydroxamic acid, SAHA) in patients with recurrent and/or metastatic head and neck cancer. Invest New Drugs 2008, 26:8I-87.

42. Finnin MS, Donigian JR, Cohen A, Richon VM, Rifkind RA, Marks PA, et al:: Structures of a histone deacetylase homologue bound to the TSA and SAHA inhibitors. Nature 1999, 40I:188-193.

43. Acharya MR, Sparreboom A, Venitz J, Figg WD: Rational development of histone deacetylase inhibitors as anticancer agents: a review. Mol Pharmacol 2005, 68:917-932.

44. Bolden JE, Peart MJ, Johnstone RW: Anticancer activities of histone deacetylase inhibitors. Nat Rev Drug Discov 2006, 5:769-784

45. Kraker AJ, Mizzen CA, Hartl BG, Miin J, Allis CD, Merriman RL: Modulation of histone acetylation by [4-(acetylamino)- $\mathrm{N}-(2-$ amino-phenyl) benzamide] in HCT-8 colon carcinoma. Mol Cancer Ther 2003, 2:40I-408.

46. Prakash S, Foster BJ, Meyer M, Wozniak A, Heilbrun LK, Flaherty L, et al:: Chronic oral administration of Cl-994: a phase I study. Invest New Drugs 2001, 19: I-II.

47. Nemunaitis J], Orr D, Eager R, Cunningham CC, Williams A, Mennel $\mathrm{R}$, et al.: Phase I study of oral $\mathrm{Cl}-994$ in combination with gemcitabine in treatment of patients with advanced cancer. Cancer J 2003, 9:58-66.

48. Pauer LR, Olivares J, Cunningham C, Williams A, Grove W, Kraker $\mathrm{A}$, et al.: Phase I study of oral $\mathrm{Cl}-994$ in combination with car- 
boplatin and paclitaxel in the treatment of patients with advanced solid tumors. Cancer Invest 2004, 22:886-896.

49. Undevia SD, Janisch L, Schilsky RL, Loury D, Balasubramanian S, Mani C, et al.: Phase I study of the safety, pharmacokinetics (PK) and pharmacodynamics (PD) of the histone deacetylase inhibitor (HDACi) PCI-2478I. J Clin Oncol 2008, 26:

50. Undevia SD, Kindler HL, Janisch L, Olson SC, Schilsky RL, Vogelzang $\mathrm{NJ}$, et al.: A phase I study of the oral combination of CI-994, a putative histone deacetylase inhibitor, and capecitabine. Ann Oncol 2004, I 5: |705-I7II.

51. Nakajima H, Kim YB, Terano H, Yoshida M, Horinouchi S: FR90 I 228, a potent antitumor antibiotic, is a novel histone deacetylase inhibitor. Exp Cell Res 1998, 241: I26-133.

52. Ueda H, Nakajima H, Hori Y, Fujita T, Nishimura M, Goto T, et al.: FR90 I 228, a novel antitumor bicyclic depsipeptide produced by Chromobacterium violaceum No. 968. I. Taxonomy, fermentation, isolation, physico-chemical and biological properties, and antitumor activity. J Antibiot (Tokyo) 1994 47:30I-310.

53. Doss HH, Jones SF, Infante JR, Spigel DR, Willcutt N, Lamar R, et al. A phase I trial of romidepsin in combination with gemcitabine in patients with pancreatic and other advanced solid tumors. J Clin Oncol 2008, 26:

54. Piekarz R, Luchenko V, Draper D, Wright JJ, Figg WD, Fojo AT, et al.: Phase I trial of romidepsin, a histone deacetylase inhibitor given on days one, three and five in patients with thyroid and other advanced cancers. J Clin Oncol 2008, 26:

55. Klimek VM, Fircanis S, Maslak P, Guernah I, Baum M, Wu N, et al: Tolerability, pharmacodynamics, and pharmacokinetics studies of depsipeptide (romidepsin) in patients with acute myelogenous leukemia or advanced myelodysplastic syndromes. Clin Cancer Res 2008, 14:826-832.

56. Schrump DS, Fischette MR, Nguyen DM, Zhao M, Li X, Kunst TF, et al.: Clinical and molecular responses in lung cancer patients receiving Romidepsin. Clin Cancer Res 2008, I 4:188-198.

57. Stadler WM, Margolin K, Ferber S, McCulloch W, Thompson JA: A phase II study of depsipeptide in refractory metastatic renal cell cancer. Clin Genitourin Cancer 2006, 5:57-60.

58. Piekarz RL, Frye AR, Wright J], Steinberg SM, Liewehr DJ, Rosing DR, et al:: Cardiac studies in patients treated with depsipeptide, FK228, in a phase II trial for T-cell lymphoma. Clin Cancer Res 2006, I 2:3762-3773.

59. Leoni F, Fossati G, Lewis EC, Lee JK, Porro G, Pagani P, et al.: The histone deacetylase inhibitor ITF2357 reduces production of pro-inflammatory cytokines in vitro and systemic inflammation in vivo. Mol Med 2005, I I:I-I5.

60. Viviani S, Bonfante V, Fasola C, Valagussa P, Gianni AM: Phase II study of the histone-deacetylase inhibitor ITF2357 in relapsed/refractory Hodgkin's lymphoma patients. J Clin Oncol 2008, 26:.

61. Galli M, Salmoiraghi S, Golay J, Gozzini A, Bosi A, Crippa C, et al.: A phase II multiple dose clinical trial of histone deacetylase inhibitor ITF2357 in patients with relapsed or progressive multiple myeloma: preliminary results. Blood 2007, I I (1 I ):.

62. Bali P, Pranpat M, Bradner J, Balasis M, Fiskus W, Guo F, et al.: Inhibition of histone deacetylase 6 acetylates and disrupts the chaperone function of heat shock protein 90: a novel basis for antileukemia activity of histone deacetylase inhibitors. Biol Chem 2005, 280:26729-26734.

63. Giles F, Fischer T, Cortes J, Garcia-Manero G, Beck J, Ravandi F, et al:: A phase I study of intravenous LBH589, a novel cinnamic hydroxamic acid analogue histone deacetylase inhibitor, in patients with refractory hematologic malignancies. Clin Cancer Res 2006, I 2:4628-4635.

64. Rathkopf DE, Wong BY, Ross RW, George DJ, Picus J, Tanaka E, et al.: A phase I study of oral panobinostat (LBH589) alone and in combination with docetaxel (Doc) and prednisone in castration-resistant prostate cancer (CRPC). J Clin Oncol J Clin Oncol. 2008 Jun 20;26(I8):2959-65. 2008, 26( I 8):2959-2965.

65. Duvic M, Vanaclocha F, Bernengo MG, Okada C, Breneman D, Zinzani PL, et al.: Phase II study of oral panobinostat (LBH589), a potent pan-deacetylase inhibitor, in patients with refractory Cutaneous T-cell Lymphoma (CTCL). J Clin Oncol 2008, 26:

66. Zhou N, Moradei O, Raeppel S, Leit S, Frechette S, Gaudette F, et al:: Discovery of N-(2-aminophenyl)-4-[(4-pyridin-3-ylpyrimidin- 2-ylamino)methyl]benzamide (MGCDO I03), an orally active histone deacetylase inhibitor. J Med Chem 2008, 5 I:4072-4075.

67. Tourneau CL, Siu LL: Promising antitumor activity with MGCDOI03 a novel isotype-selective histone deacetylase inhibitor. Expert Opin Investig Drugs 2008, 17:1247-1254.

68. Siu LL, Pili R, Duran I, Messersmith WA, Chen EX, Sullivan R, et al.: Phase I study of MGCDO 103 given as a three-times-per-week oral dose in patients with advanced solid tumors. J Clin Oncol 2008, 26:1940-1947.

69. Garcia-Manero G, Assouline S, Cortes J, Estrov Z, Kantarjian H, Yang $\mathrm{H}$, et al:: Phase I study of the oral isotype specific histone deacetylase inhibitor MGCDOIO3 in leukemia. Blood 2008, I | 2:98|-989.

70. Hurwitz H, Nelson B, O'Dwyer PJ, Chiorean EG, Gabrail N, Laille E, et al:: Phase I/II: The oral isotype-selective HDAC inhibitor MGCDOIO3 in combination with gemcitabine (Gem) in patients (pts) with refractory solid tumors. J Clin Oncol 2008, 26:. abst \# 4625. Ref Type: Journal (Full)

71. Crump M, Andreadis C, Assouline S, Rizzieri D, Wedgwood A, McLaughlin $\mathrm{P}$, et al.: Treatment of relapsed or refractory nonhodgkin lymphoma with the oral isotype-selective histone deacetylase inhibitor MGCDOI03: Interim results from a phase II study. I Clin Oncol 2008, 26:

72. Bociek RG, Kuruvilla J, Pro B, Wedgwood A, Li Z, Drouin M, et al.: Isotype-selective histone deacetylase (HDAC) inhibitor MGCDOIO3 demonstrates clinical activity and safety in patients with relapsed/refractory classical Hodgkin Lymphoma (HL). J Clin Oncol 2008, 26:.

73. Saito A, Yamashita T, Mariko Y, Nosaka Y, Tsuchiya K, Ando T, et al.: A synthetic inhibitor of histone deacetylase, MS-27-275, with marked in vivo antitumor activity against human tumors. Proc Natl Acad Sci USA 1999, 96:4592-4597.

74. Hess-Stumpp H, Bracker TU, Henderson D, Politz O: MS-275, a potent orally available inhibitor of histone deacetylases - the development of an anticancer agent. Int J Biochem Cell Biol 2007, 39: 1388-1405.

75. Gojo I, Jiemjit A, Trepel JB, Sparreboom A, Figg WD, Rollins S, et al. Phase I and pharmacologic study of MS-275, a histone deacetylase inhibitor, in adults with refractory and relapsed acute leukemias. Blood 2007, 109:278I-2790.

76. Gore L, Rothenberg ML, O'Bryant CL, Schultz MK, Sandler AB, Coffin $D$, et al.: A Phase I and Pharmacokinetic Study of the Oral Histone Deacetylase Inhibitor, MS-275, in Patients with Refractory Solid Tumors and Lymphomas. Clin Cancer Res 2008, 14:4517-4525.

77. Hauschild A, Trefzer U, Garbe C, Kaehler KC, Ugurel S, Kiecker F, et al.: Multicenter phase II trial of the histone deacetylase inhibitor pyridylmethyl-N-4-\{[(2-aminophenyl)-carbamoyl]-benzyl\}-carbamate in pretreated metastatic melanoma. Melanoma Res 2008, 18:274-278.

78. Buggy JJ, Cao ZA, Bass KE, Verner E, Balasubramanian S, Liu L, et al.: CRA-02478 I: a novel synthetic inhibitor of histone deacetylase enzymes with antitumor activity in vitro and in vivo. Mol Cancer Ther 2006, 5: I309-1317.

79. Pili R, Kruszewski MP, Hager BW, Lantz J, Carducci MA: Combination of phenylbutyrate and 13 -cis retinoic acid inhibits prostate tumor growth and angiogenesis. Cancer Res 200I, 6I:1477-1485

80. Camacho LH, Olson J, Tong WP, Young CW, Spriggs DR, Malkin MG Phase I dose escalation clinical trial of phenylbutyrate sodium administered twice daily to patients with advanced solid tumors. Invest New Drugs 2007, 25:131-138.

81. Carducci MA, Gilbert J, Bowling MK, Noe D, Eisenberger MA, Sinibaldi V, et al: A Phase I clinical and pharmacological evaluation of sodium phenylbutyrate on an 120-h infusion schedule. Clin Cancer Res 2001, 7:3047-3055.

82. Gilbert J, Baker SD, Bowling MK, Grochow L, Figg WD, Zabelina Y et al: A phase I dose escalation and bioavailability study of oral sodium phenylbutyrate in patients with refractory solid tumor malignancies. Clin Cancer Res 200I, 7:2292-2300.

83. Sung MW, Waxman S: Combination of cytotoxic-differentiation therapy with 5-fluorouracil and phenylbutyrate in patients with advanced colorectal cancer. Anticancer Res 2007, 27:995-1001.

84. Maslak P, Chanel S, Camacho LH, Soignet S, Pandolfi PP, Guernah I, et al: Pilot study of combination transcriptional modulation 
therapy with sodium phenylbutyrate and 5 -azacytidine in patients with acute myeloid leukemia or myelodysplastic syndrome. Leukemia 2006, 20:212-217.

85. Plumb JA, Finn PW, Williams RJ, Bandara MJ, Romero MR, Watkins C], et al: Pharmacodynamic response and inhibition of growth of human tumor xenografts by the novel histone deacetylase inhibitor PXD I 0 I. Mol Cancer Ther 2003, 2:72I-728.

86. Steele NL, Plumb JA, Vidal L, Tjornelund J, Knoblauch P, Rasmussen $A$, et al.: A phase I pharmacokinetic and pharmacodynamic study of the histone deacetylase inhibitor belinostat in patients with advanced solid tumors. Clin Cancer Res 2008, 14:804-8|0.

87. Gimsing P, Hansen M, Knudsen LM, Knoblauch P, Christensen IJ, Ooi $\mathrm{CE}$, et al.: A Phase I clinical trial of the histone deacetylase inhibitor belinostat (PXD I O I) in patients with advanced haematological neoplasia. Eur J Haematol 2008, 81:170-176.

88. Mackay H, Hirte HW, Covens A, MacAlpine K, Wang L, Tsao MS, et al.: A phase II trial of the histone deacetylase inhibitor belinostat (PXDIOI) in patients with platinum resistant epithelial ovarian tumors and micropapillary/borderline (LMP) ovarian tumors. A PMH phase II consortium trial. J Clin Oncol 2008, 26:.

89. Gottlicher M, S Minucci, P Zhu, OH Kramer, A Schimpf, S Giavara, et al:: Valproic acid defines a novel class of HDAC inhibitors inducing differentiation of transformed cells. EMBO J 200I, 20:6969-6978.

90. Kuendgen A, Schmid M, Schlenk R, Knipp S, Hildebrandt B, Steidl C, et al:: The histone deacetylase (HDAC) inhibitor valproic acid as monotherapy or in combination with all-trans retinoic acid in patients with acute myeloid leukemia. Cancer 2006, 106: I I2-II9.

91. Bug G, Ritter M, Wassmann B, Schoch C, Heinzel T, Schwarz K, et al.: Clinical trial of valproic acid and all-trans retinoic acid in patients with poor-risk acute myeloid leukemia. Cancer 2005 , 104:27|7-2725.

92. Chavez-Blanco A, Segura-Pacheco B, Perez-Cardenas E, Taja-Chayeb L, Cetina L, Candelaria M, et al.: Histone acetylation and histone deacetylase activity of magnesium valproate in tumor and peripheral blood of patients with cervical cancer. A phase study. Mol Cancer 2005, 4:22.

93. Atmaca A, Al-Batran SE, Maurer A, Neumann A, Heinzel T, Hentsch $B$, et al.: Valproic acid (VPA) in patients with refractory advanced cancer: a dose escalating phase I clinical trial. $\mathrm{Br}$ J Cancer 2007, 97:177-182.

94. Shapiro TA, Fahey JW, nkova-Kostova AT, Holtzclaw WD, Stephenson KK, Wade KL, et al.: Safety, tolerance, and metabolism of broccoli sprout glucosinolates and isothiocyanates: a clinical phase I study. Nutr Cancer 2006, 55:53-62.

95. Chiao JW, Wu H, Ramaswamy G, Conaway CC, Chung FL, Wang L, et al.: Ingestion of an isothiocyanate metabolite from cruciferous vegetables inhibits growth of human prostate cancer cell xenografts by apoptosis and cell cycle arrest. Carcinogenesis 2004, 25: | 403-| 408.

96. Lu L, Liu D, Ma X, Beklemishev A, Seiter K, Ahmed T, et al.: The phenylhexyl isothiocyanate induces apoptosis and inhibits leukemia cell growth in vivo. Oncol Rep 2006, 16:1363-1367.

97. Lu Q, Lin X, Feng J, Zhao X, Gallagher R, Lee MY, et al.: Phenylhexyl isothiocyanate has dual function as histone deacetylase inhibitor and hypomethylating agent and can inhibit myeloma cell growth by targeting critical pathways. J Hematol Oncol 2008, I:6.

98. Ma X, Fang Y, Beklemisheva A, Dai W, Feng J, Ahmed T, et al.: Phenylhexyl isothiocyanate inhibits histone deacetylases and remodels chromatins to induce growth arrest in human leukemia cells. Int J Oncol 2006, 28:1287-1293.

99. Wang LG, Beklemisheva A, Liu XM, Ferrari AC, Feng J, Chiao JW: Dual action on promoter demethylation and chromatin by an isothiocyanate restored GSTPI silenced in prostate cancer. Mol Carcinog 2007, 46:24-31.

100. Wang LG, Liu XM, Fang Y, Dai W, Chiao FB, Puccio GM, et al.: Derepression of the $\mathrm{p} 2 \mathrm{I}$ promoter in prostate cancer cells by an isothiocyanate via inhibition of HDACs and c-Myc. Int J Oncol 2008, 33:375-380.

101. Qian DZ, Wang X, Kachhap SK, Kato Y, Wei Y, Zhang L, et al.: The histone deacetylase inhibitor NVP-LAQ824 inhibits angiogenesis and has a greater antitumor effect in combination with the vascular endothelial growth factor receptor tyrosine kinase inhibitor PTK787/ZK222584. Cancer Res 2004, 64:6626-6634.

102. Remiszewski SW, Sambucetti LC, Bair KW, Bontempo J, Cesarz D, Chandramouli N, et al:: $\mathbf{N}$-hydroxy-3-phenyl-2-propenamides as novel inhibitors of human histone deacetylase with in vivo antitumor activity: discovery of (2E)-N-hydroxy-3-[4-[[(2hydroxyethyl)[2-(IH-indol-3-yl)ethyl]amino]methyl]phenyl]-2-propenamide (NVP-LAQ824). J Med Chem 2003, 46:4609-4624.

103. Hurtubise A, Momparler RL: Effect of histone deacetylase inhibitor LAQ824 on antineoplastic action of 5-Aza-2'-deoxycytidine (decitabine) on human breast carcinoma cells. Cancer Chemother Pharmacol 2006, 58:618-625.

104. Grant S: The novel histone deacetylase inhibitor NVPLAQ824: an addition to the therapeutic armamentarium in leukemia? Leukemia 2004, 18:1931-1933.

105. Atadja P, Hsu M, Kwon P, Trogani N, Bhalla K, Remiszewski S: Molecular and cellular basis for the anti-proliferative effects of the HDAC inhibitor LAQ824. Novartis Found Symp 2004, 259:249-266.

106. Atadja P, Gao L, Kwon P, Trogani N, Walker H, Hsu M, et al.: Selective growth inhibition of tumor cells by a novel histone deacetylase inhibitor, NVP-LAQ824. Cancer Res 2004, 64:689-695
Publish with BioMed Central and every scientist can read your work free of charge

"BioMed Central will be the most significant development for disseminating the results of biomedical research in our lifetime. "

Sir Paul Nurse, Cancer Research UK

Your research papers will be:

- available free of charge to the entire biomedical community

- peer reviewed and published immediately upon acceptance

- cited in PubMed and archived on PubMed Central

- yours - you keep the copyright 